\title{
A Young Woman with Coomb's Positive Severe Haemolytic Anaemia and Hodgkin Lymphoma that Responded Completely to Rituximab: A Case Report
}

\author{
Nandan Maruti Shanbhag ${ }^{1 *}$, Sneha Nandan Shanbhag ${ }^{2}$, Thembani Kenalemang ${ }^{3}$ and Rene Albertyn ${ }^{4}$ \\ ${ }^{1,3}$ Department of Oncology, Letsholathebe II Memorial Hospital, South Africa \\ ${ }^{2}$ Department of Medicine, Letsholathebe II Memorial Hospital, South Africa \\ ${ }^{4}$ Senior Researcher, Department of Paediatric Surgery, Red Cross Children's Hospital, South Africa
}

Submission: December 09, 2016; Published: January 04, 2017

"Corresponding author: Nandan Maruti Shanbhag, Department of Oncology, Letsholathebe II Memorial Hospital, Maun, Botswana, South Africa, Tel: +26776114677; Email: onco@drnandan.com

\begin{abstract}
Introduction

Lymphoma has been historically divided into a Hodgkin and Non-Hodgkin variety. There are reported cases of Hemolytic Anemia in NonHodgkin Lymphoma but Hodgkin Lymphoma very rarely also present with Hemolytic Anemias.

\section{Case presentation}

A 27-year-old African woman presented with chronic fatigue, dyspnoea, jaundice and Splenomegalie. Her blood work revealed severe anaemia (haemoglobin, $4.9 \mathrm{~g} / \mathrm{dl}$ ) with biochemical evidence of haemolysis. A direct Coomb's test was reported positive. A biopsy of the lymph nodes in the neck confirmed Hodgkin Lymphoma. Initial therapy consisted of intravenous methyl prednisolone and switched over to Oral Prednisolone. However, the patient came back with raised sugar levels and there was no clinically response. The patient continued to have lower hemoglobin levels and was transfused blood repeatedly. She was started on chemotherapy with ABVD regimen and after literature review, on Intravenous Rituximab $375 \mathrm{mg} / \mathrm{m}^{2} /$ week. The patient's hemoglobin started to rise after two doses of Rituximab therapy and completely stabilized.
\end{abstract}

\section{Conclusion}

This is the one of the rare reported case of autoimmune haemolytic anaemia that went into complete remission with rituximab after no clinical or biochemical response to Steroid Therapy. We demonstrate here that severe haemolysis associated with autoimmune haemolytic anaemia in Hodgkin Lymphoma can achieve complete clinical and biochemical response with Rituximab therapy when not amenable to steroid therapy.

Keywords: Rituximab, Haemolytic anaemia, Hodgkin lymphoma

Abbreviations: AIHA: Auto-Immune Hemolytic Anemia; HL: Hodgkin Lymphoma; LDH: Lactate Dehydrogenate; IgG: Immunoglobulin G; CT: Computed Tomography

\section{Introduction}

Though autoimmune hemolytic anemia (AIHA) is seen in Chronic Lymphoid Leukemia and Non-Hodgkin Lymphoma, it is rarely seen in Hodgkin lymphoma (HL) patients [1]."The presence of a positive direct Coombs test in the patient with Hodgkin's disease suggests active and advanced disease"[2]. Autoimmune haemolytic anaemia (AIHA) is one of the most common causes of acquired haemolytic anaemia [3]. Treatment options for AHIA patients include treating the underlying lymph proliferative disorder with cytotoxic drugs, radiotherapy and corticosteroids. Treatment with Rituximab has emerged as a new alternative with good response [4]. Our Case report demonstrates the effectiveness of this therapy.

\section{Case Presentation}

A 27-yr old pre-menopausal lady with a history of chronic alcohol abuse presented to the outpatient clinic with complaints of 'Feeling Weak', fever, blurred vision of 10 days duration. The patient had sinus tachycardia of 120 beats/min with a blood pressure of $100 / 60 \mathrm{mmHg}$ and a respiratory rate of $22 / \mathrm{min}$. 
She was a febrile. She complained of loss of weight and loss of appetite. She also complained of fever and night sweats. She is married with two young children and had stopped breast feeding her young three months back. The patient had good social and spiritual support but did feel drained physically and emotionally.

She had irregular menses with reduced flow and lasting only two days. She was seen by the physician three months earlier with similar complaints and a severe anaemia of $4.9 \mathrm{~g} / \mathrm{dl}$. She was started on steroid therapy after a combs test came positive for IgG. She was referred to the oncologist as an examination revealed multiple lymph nodes in the axilla on the right side. Her physical examination was remarkable for severe pallor, shifting dullness, Splenomegalie and bilateral lower-extremity pitting oedema. There were multiple lymph nodes in the right axilla the largest of which measured $6 \mathrm{cms}$.

The complete blood count revealed anaemia with a haemoglobin level of $7.1 \mathrm{~g} / \mathrm{dl}$, a normal reticulocyte count, Red blood cell count of $2.04 \times 10^{6} / \mu$ l and normal white cell and platelet counts. Lactate dehydrogenate (LDH) was elevated with a value of $410 \mathrm{U} / \mathrm{L}$. Peripheral smear reported Red blood cell agglutination, microcytic and anisocytosis with Leucopoenia. The direct Coombs test was positive for immunoglobulin G (IgG) antibody. The Renal Function tests were normal. Liver function tests were significant for an elevated total bilirubin level of 36 $\mu \mathrm{mol} / \mathrm{L}$, a direct bilirubin level of $13.9 \mu \mathrm{mol} / \mathrm{L}$.

Tests for Hepatitis, Human Immunodeficiency Virus, AntiNuclear antibody and Anti-Smooth Muscle antibody were negative. Ultrasound of the abdomen and pelvis revealed a large spleen measuring $13.28 \mathrm{cms}$. Computed tomography (CT) of the chest, abdomen and pelvis confirmed Splenomegalie with multiple lymph nodes in the Right Axilla. The biopsy of the lymph nodes revealed Reed Sternberg Cell diagnostic of Hodgkin Lymphoma which was Lymphocyte Depleted Reticular Subtype (Table 1).

Table 1: Haemoglobin and Haematocrit levels as before any treatment, after imitation of steroid, at the end of second week of Rituximab, at the end of fourth week of Rituximab and finally on follow up at the end of fourth and sixth month following the Rituximab therapy.

\begin{tabular}{|c|c|c|c|c|c|c|}
\hline & $\begin{array}{c}\text { First } \\
\text { Consultation }\end{array}$ & After Steroid & $\begin{array}{c}\text { Rituximab 2nd } \\
\text { weekly dose }\end{array}$ & $\begin{array}{c}\text { Rituximab 4th } \\
\text { weekly dose }\end{array}$ & $\begin{array}{c}\mathbf{4} \text { months after } \\
\text { Therapy }\end{array}$ & $\begin{array}{c}\mathbf{6} \text { months after } \\
\text { Therapy }\end{array}$ \\
\hline $\begin{array}{c}\text { Haemaglobin } \\
\text { levels g/dL }\end{array}$ & 4.9 & 7.1 & 8.60 & 13.7 & 13.3 & 13.8 \\
\hline Haematocrit \% & & 22.4 & 28.6 & 40.8 & 39 & 40.9 \\
\hline
\end{tabular}

\section{Results}

The patient had undergone transfusions with several units of packed cells and was on twice daily doses of oral prednisolone $10 \mathrm{mg}$. After corticosteroid therapy, the patient's haemoglobin improved only marginally, and she continued to require blood transfusions. Consequent to the initiation of steroid, her sugars started to raise with Fasting Blood sugars reaching 18.1 $\mu \mathrm{mol} / \mathrm{L}$. She was started on Subcutaneous Insulin twice daily. After reviewing the Literature that has demonstrated benefit of rituximab treatment in haemolytic anaemia's, steroid was tapered and the patient was started on rituximab therapy at a dose of $375 \mathrm{mg} / \mathrm{m}^{2}$ every week.

A total of four doses were administered over a period of four weeks. The patient showed marked clinical improvement after two weeks of therapy and had the haemoglobin rise to 13.7 $\mathrm{g} / \mathrm{dL}$ at the end of the four weeks. Subsequently, steroids and insulin were stopped completely as her Fasting Blood sugars normalised. She continued with her monthly chemotherapy cycles and had complete resolution of all the disease. After four months of Rituximab Therapy, her haemoglobin remained at 13.3 $\mathrm{g} / \mathrm{dl}$. On follow up after six months of therapy, her haemoglobin remains at $13.8 \mathrm{~g} / \mathrm{dl}$ and she is completely symptom free.

\section{Discussion}

Haemolytic Anaemias with an underlying proliferative disorder have been treated with various drugs and radiotherapy
$[5,6]$. Literature review suggested that the first line of treatment has always almost been a corticosteroid [7,8]. Rituximab is a monoclonal antibody which is active against CD20 and has been used in the treatment of CD20 positive Non-Hodgkin lymphoma and Lymphocyte dominant Hodgkin Lymphoma. Rituximab has been used to treat Haemolytic anaemia who did not respond to conventional steroid therapy or had a relapse $[9,10]$. To the best of our knowledge, our case is a rare presentation of autoimmune haemolytic anaemia in a Lymphocyte Depleted Hodgkin Lymphoma that did not respond to steroids but showed a complete and sustained response to Rituximab.

\section{Conclusion}

It is clear from this case report that Rituximab caused complete resolution of the Hemolytic Anemia in Hodgkin lymphoma patient resistant to corticosteroid therapy and can be considered as a line of treatment in similar cases.

\section{Author Contributions}

NMS is the treating Oncologist, SNS is the treating physician, TK is treating chemotherapy nurse, RA helped with literature review and sourcing articles.

\section{References}

1. Levine AM, Thornton P, Forman SJ, Van Hale P, Holdorf D, et al. (1980) Positive Coombs test in Hodgkin's disease: Significance and implications. Blood 55(4): 607-611. 


\section{Cancer Therapy \& Oncology International Journal}

2. Feng Q, Zak D, Daya R (2012) Autoimmune hemolytic anemia and classical Hodgkin lymphoma: A case report and literature review. Clin Adv Hematol Oncol 10(4): 270-276.

3. Gupta S, Szerszen A, Nakhl F, Varma S, Gottesman A, et al. (2011) Severe refractory autoimmune hemolytic anemia with both warm and cold autoantibodies that responded completely to a single cycle of rituximab: A case report 5: 156.

4. Morselli M, Luppi M, Potenza L, Tonelli S, Dini D, et al. (2002) Mixed warm and cold autoimmune hemolytic anemia: Complete recovery after 2 courses of rituximab treatment. Blood 99(9): 3478-3479.

5. Bowdler AJ, Glick IW (1966) Autoimmune hemolytic anemia as the herald state of Hodgkin's disease. Annals of Internal Medicine 65(4): 761-767.

6. May RB, Bryan JH (1976) Autoimmune hemolytic anemia and Hodgkin disease. The Journal of Pediatrics 89(3): 428-9.
7. Chu JY, McElfresh AE, Waeltermann RM (1976) Autoimmune hemolytic anemia as a presenting manifestation of Hodgkin disease. J Pediatr 89(3): 429-430.

8. Pasini S, Pasini G, Candoli P, Guardigni L (1992) Hodgkin's disease presenting as hemolytic anemia. Haematologica 77(1): 95.

9. Zaja F, Iacona I, Masolini P, Russo D, Sperotto A, et al. (2002) B-cell depletion with rituximab as treatment for immune hemolytic anemia and chronic thrombocytopenia. Haematologica 87(2): 189-195.

10. Bauduer F (2001) Rituximab: Avery efficient therapy in cold agglutinins and refractory autoimmune haemolytic anaemia associated with CD20-positive, low-grade non-Hodgkin's lymphoma. Br J Haematol 112(4): 1085-1086

Your next submission with JuniperPublishers will reach you the below assets

- Quality Editorial service

- Swift Peer Review

- Reprints availability

- E-prints Service

- Manuscript Podcast for convenient understanding

- Global attainment for your research

- Manuscript accessibility in different formats (Pdf, E-pub, Full Text, Audio)

- Unceasing customer service

Track the below URL for one-step submission https://juniperpublishers.com/online-submission.php 